


\section{The Vocational Regime in Art: On Myths and Performativity}

\section{Mathilde Legret}

How and when does the will to be an artist appear? 'Vocation' is one of the common answers to this question, it is as well a common social representation of what an artist must be. The 'vocational regime' of activity is contradictory to the 'craft regime' and the 'professional regime'. According to Pierre Bourdieu, the vocational regime is characterized as an 'economic world reversed' (Bourdieu 1992). In other words, people don't work to earn their living, but they earn their living to be able to practice a profession. The artistic activities are practised within this vocational regime and in accordance with the current hegemonic values in the modern art world. What are the characteristics of the vocational regime and what are its manifestations and consequences? This essay tries to answer these question and explore the notion of vocation in the art world through an analysis of extracts from interviews I had with artists.

\section{Social Contextualization of the Key Notions}

The perception we have about artists and art is neither an absolute value or universal and timeless. The role artists have in the society has changed through times. The representation of the artist as a creator and the representation of the art as a creation came from the Renaissance. Before the 15th century, the word 'creation' was reserved for the acts of God. Those we would today call 'artists' were 'craftsmen'. Art in the way we understand it today referred to the technique and the craft, and to the mechanical arts, opposed to the noble liberal arts. The artist was at the bottom of the ladder and a part of a guild, and his production was unsigned and collective. The Renaissance led to the modern understanding of art and artists. The disruptions in the rules of representation and the birth of perspective caused an evolution of the artist's status: he was no longer a craftsman, but a scholar and a savant. The most iconic figure in this evolution was Leonardo da Vinci. Following his role mode, artists claimed to have technical knowledge as well as a theoretical one (about perspective, light, anatomy...), and their activities were included among the 'liberal arts'. At the same time, more importance was given to the personal style, and the artworks were no longer unsigned. This was also the birth of the notion of art as an impetus for contemplation.

The idea of art as a vocational activity became progressively widespread during the $19^{\text {th }}$ century, and with it the perception of the creation and the particular style as a way of the artist's expression became the norm. From the end of the 17th to the 19th century, two trends were observable:

1. A specialization and theorization of the artistic knowledge. The starting points of these evolutions were the academies, developed during the 15th century in Italy and across Europe during the 17th and 18th centuries. The academies were based on an elitist selection and a strong codification through theoretical courses leading to an intellectualization of the profession. These institutions did not allow for innovation and became progressively more and more inflexible and rigid, encouraging equally rigid thought canons and norms. 
2. A multiplication of new movements carried by marginalized artists trained in workshops. Their market was shared between public orders and galleries which played an essential role (e.g. for impressionism or realism).

Two opposed regimes of activity emerged from these two trends:

1. The professional regime which comprises the artists from the Academy who obey its codes and rules.

2. The vocational regime defined by personal talent, a vocation, a calling (Heinich 1996). The artist is seen as predestined to choose the activity. The individual does not choose this profession by interest: he or she follows something which comes from the inside.

\section{Definition of the Vocational Regime}

The vocational regime refers to common social representations of what an artist must be: somebody who devotes himself to artistic activities by vocation. Having a vocation also refers to a personal feeling, an inner experience. The activities judged as vocational are rare, they imply the idea of mission, of service to the community, of self-sacrifice and selflessness without a cost - benefit analysis. These vocations have acquired an exemplary cultural status which utilizes a religious vocabulary, using terms such as a calling, a profession of faith and confession. If we are called by a vocation, we follow it, we do not cheat on it, we sacrifice everything for it... Thanks to this vocation, we now know what to do and what to make of ourselves (Schlanger 1997, 77).

'I have to do it. I think for a lot of my friends who are artists they have to do it. Don't know why.' - Ursula Hübner

From an etymological point of view, vocation comes from the Latin word vocare which means 'to be called'. It also has a religious origin, from the German Beruf, which means vocation and profession at the same time. The origin of this double signification comes from Luther's translation of the Bible, in which he bound together work and religious duty, along with the ethic of the work (Sapiro 2007). The vocation is a transcendental calling which forces the individual to follow it; it is a spiritual calling which imposes a message and a role and transforms the one called upon.

Outside of the religious realm, the theme of vocation became dominant in the western collective unconscious only during the 17th century. In the artistic field, the idea of vocation became a component of the definition of the artist at the end of the 19th century with the rise of romanticism. Here, vocation is forced and endured by the individual, especially the religious and artistic vocation. Both of them lead to a fusion of the public and private realm and the birth of a person with a special social status. This individual is most of the times marginalized and the status can bring difficulties to social adjustments.

I think you are born into a community and maybe you can feel there as an outsider. I had no bad experience because I had, my parents were wonderful parents, but the community, I don't, I ... It's more psychology, psychological things, why you become an outsider. And there are some reasons. And I know some of my friends who are also artists, they are also outsiders, you 
can be an outsider because you are very ... for instance very intelligent. And ... the surrounding is not the same, so you feel the gap between ... It was not that I was very intelligent but I, maybe I was really sensitive. And I couldn't deal with the others who were very strong and ...'

'But then I went to Vienna to work with Maria Lassnig, she is a famous painter, and she was my teacher there and ... This was very... yes this was destiny to work...'

But unlike the religious vocation, which is supervised by religious institutions, the artistic vocation seems to be formed outside of every social and restrictive organization. Furthermore, the extreme opposite of the vocational regime can be found in the organized professions and especially in the bureaucracy: to the routine of the tasks and the interchangeable nature of their subordinates, the artistic activities oppose the charisma of a unique personality, whose name constitutes the symbolic capital. The certified expertise is opposed to the individual gift as is the utility principle that rules the capitalist societies to the free symbolic goods (Sapiro 2007).

The vocational regime has been consolidated and imposed thanks to two elements:

1. The social and historical conditions and the progressive recognition of the artistic activities as vocational and autonomous activities.

2. The individual compliance to the ideas according to whom the artistic activities are practised only by people following a vocation they declare.

The interview with Ursula Hübner confirmed this individual compliance and the ways in which the artists perform their roles. Another conversation with a student at the Art Academy illustrated the idea of self-sacrifice as a part of the artist's life: this student told me about her financial restrictions, especially because of the cost of the materials. But at the same time, she did not have the time to take up a job next to her artistic activity. She confessed it was difficult for her and she had no private life, only to add 'it's normal at the beginning. [...] When you are an artist, you forget about yourself. [...] The only thing that matters is to see the sculpture at the end.' Another conversation with Ursula Hübner, who told me that she used her small apartment to show the works of other artists, demonstrates the selflessness among artists:

'And this was something I did, and I did not get any money for this. It was my idea, I wanted to do it, and it opened in a party or ... the times we had a lot of wine, I showed the works, and if it happened that one sold a work, he got the whole money because I was not a gallerist. Only a party girl (laughs). But I think the best things sometimes you don't do it for money.'

\section{Consequences of the Vocational Regime and the Myth of the Innocent Eye}

We must not buy into this common idea according to which artistic vocation is socially incriminated. In fact, we can observe a significant rate of its social reproduction among artists (and especially among well-known artists). This points us to the role of the family organization in the 'vocation' of the individual: education to the 'good taste', transmission of the cultural capital in all of his forms (institutionalized, objectified, embodied), habitus... (Bourdieu, 1969).

'[Painting] was not interesting stuff for [my parents], but.... 
'My parents had a kind of [custom] to go to the theatre, every month.'

'But my mother, I think it was also very important, my parents they were interested in good stuff, they were listening good music, interested in good literature. My mother wasn't interested in looking at magazines like other mothers of my girlfriends. She wasn't interested in this stuff, and she was interested in new Austrian literature for instance. And she bought all these good books, and she saw the movies of Ingmar Bergman for instance. I think for me and my brother it was important; they were not rich, but they had a good taste.'

\section{'My father he loves Mozart for instance, he loves this.'}

More broadly, among all art professions, it is the plastic artists who come from the most privileged milieu $(30 \%$ of them have a senior executive as a father). We can observe as well the influence of the milieu among writers and careers in the performing arts $(26 \%)$. More precisely, $8 \%$ of the writers, $5 \%$ of the careers in the performing arts and $3 \%$ of the plastic artists have a father who practices or has practised a profession in the field of information, arts and performances. It's much more than for the whole working-age adults: from 2009 to 2011 in France, 0,4\% of the worker's fathers are or were workers in the field of information, arts and performances (Gouyon \& Patureau 2013).

The family doesn't only pass the cultural capital and the habitus. It can provide the money necessary to the studies, the risk-taking tendency, the knowledge of the milieu and the network (Lafarrère 1998).

\section{The Myth of the Autodidact Artist}

The myth of the autodidact artist is a heritage from the first conflict situation between the Academy and the first artists who emerged from the vocational regime during the 19th century. The idea behind was one of the artists having to be freed from every academic constraint: he or she was to be a free individual who must express only his or her artistic personality and his or her creativity. Art was to be seen as the very place of this individuality and subjectivity. This myth circulated in particular with the death of Van Gogh (Heinich 1991). The autodidact training of Van Gogh has been highlighted through times and his biographers often emphasized it disproportionately. This component of his life is partly true and false: Van Gogh trained partly through contact with his contemporaries and thanks to his brother Théo who was an art dealer and who sent him many engravings. If we analyse Van Gogh's life, we observe the emergence of this paradoxical idea according to which we do not always need to train in Fine Art Schools to be an artist, and it can be even beneficial not to have done any training.

In fact, in 2009 in France for instance, $27 \%$ of the artists have a degree equal or superior to a three-year Higher Education diploma (against $18 \%$ of the working-age adults). In detail, $53 \%$ of the writers and $37 \%$ of the plastic artists fall into this case (Gouyon \& Patureau 2013). However, the schooling is often minimized in the artists' representations. The sociologist Vincent Troger observed that while doctors or senior executives often mention their training, the art world perpetuates a mystery. Often, the artist's biography begins with the date of birth and goes directly onto the first exhibition 
date. For some famous artists, especially for those of the 1960s and 1970s, the question of the artistic training is never evoked (e.g. Warhol and Pollock).

The training is often minimized in the artists' representations, but it is in fact a passport enabling them to be a part of a community (Thornton, 2009). During the 1960s, the Masters of Fine Art began to be one of the steps in the legitimization of an artist. Today, there are about 20 select art schools in the USA and to be an artist without any diploma is nowadays difficult. The Art Schools are as well places where artists learn codes, how to talk about their art and how to conceptualize their art during 'critique sessions' (Thornton, 2009): these painful rituals are now fully integrated into the art world, it has its conventions and hierarchy, even if they are not directly shown. At the end of the Art School, students still need an outside validation (buyers, museum...) to really consider themselves as artists. But the diploma is a part of the process: it enables them to be a part of a community, the artists' community.

II think it's important to study art. I know it's so hard if you didn't go to an art school to become an artist, an accepted artist, as an autodidact. I don't know why but I think really that the reason is not ... You sometimes feel when the people didn't measure with others in the art university or art group. I don't know why but I think it's important. And sometimes I have some students who ended the art university, and they do some stuff, but don't come very often, or they do it as they want to do, and they are really good. It doesn't matter. But you have to be in this surrounding., [...] you have to be in this community.'

\section{Conclusion}

The vocational regime has been consolidated and imposed not only by institutions and the socio-historical context, but also by the artists themselves. This idea of the 'artistic vocation' supposes the idea of a mission, of a service to the community, of self-sacrifice and selflessness, and the artists perform these common social representations. The myth of the autodidact artist goes along with this idea of vocation: art world is the place of individuality, and of an extreme subjectivity, the artist thanks to his or her cultural innocence can create outside of every canon and norm. These myths began to circulate after the romanticist movement in literature and the impressionist and realist movements in paintings and hinder the role of the socialization and the transmission of cultural capital from the social environment. Artists use and have accepted this common idea about themselves, carrying on the social representation of their activities.

Bourdieu, Pierre and Darbel, Alain. 1969. L'Amour de l'art. Les musées d'art européens et leur public, Paris: Minuit, coll. 'Critique'.

Bourdieu, Pierre. 1984 [1968]. 'Outline of a Sociological Theory of Art Perception'. From: The Field of Cultural Production Reader. Columbia University Press.

Bourdieu, Pierre. 2010 [1979]. Distinction. A Social Critique of the Fudgment of Taste. London/New York: Routledge.

Gouyon, Marieand \& Patureau, Frédérique. 2013. 'Les métiers artistiques : des conditions d'emploi spécifiques, des disparités de revenus marquées'. France, portrait social, édition. Paris: Insee. 
Heinich, Nathalie. 1991. La Gloire de Van Gogh. Essai d'anthropologie de l'admiration, Paris: Éditions de Minuit, coll. 'Critique'

Heinich, Nathalie. 1996. Etre artiste. Les transformations du statut des peintres et des sculpteurs, Paris: Klincksieck.

Laferrère, Armand.1998. 'Devenir travailleur indépendant'. Économie et statistique 319-320.

Sapiro, Gisèle. 1998. 'La vocation artistique entre don et don de soi'. From: Actes de la recherche en sciences sociales 2007/3 ( $\left.\mathrm{n}^{\circ} 168\right): 4-11$. DOI 10.3917/arss. 168.0004

Schlanger, Judith. 1997. La vocation, Paris: Seuil.

Thornton, Sarah. 2009. Seven Days in the Art World. London: Granta Books.

Troger, Vincent. 2001. 'Art contemporain: création, élitisme ou spéculation?', Sciencces Humaines $\mathrm{n}^{\circ} 117$, Paris. 